\title{
The role of parent-initiated motivational climate in the development of overtraining syndrome in adolescent elite athletes: a review study
}

\section{Role rodičovského motivačního klima v rozvoji syndromu přetrénování u mladých vrcholových sportovců: přehledová studie}

\author{
Zuzana Frydrychová, Kateřina Bartošová, Sára Hutečková
}

Faculty of Arts, Masaryk University, Brno

\begin{abstract}
Parents are not only gatekeepers to sport, they have significant influence on how young athlete perceives and interprets the sport experience. Their influence is mediated through the parent-initiated motivational climate and is not limited to sport environment, but also to non-sport environment. The quality of parent-child relationship is considered to be a predictor of motivation, level of perceived stress and enjoyment of activities in young athlete. It is supposed overtraining as a multifactorial in nature and that non-sport stress may be a contributing factor. The main purpose of this study is to review empirical research works examining the parent-initiated motivational climate in the context of youth elite sport and its potential influence on young elite athlete. Moreover, the study provides theoretical background of the parent-initiated motivational climate in the context of sport participation. This study reviewed empirical research works of quantitative and qualitative research design. From all searched works from 1992 to 2016, fourteen studies fulfilled set requirements. Two qualitative studies focusing on the parent-initiated motivational climate and its relation to overtraining were found out. These studies supported the assumption that non-sport stress contribute in the development of overtraining. Even though no research studies with quantitative research design examining this relationship were found out, they supported the relationship between parent-initiated motivational climate and psychological outcomes associated with sport participation, such as maladaptive behavioural patterns, that are considered to be risks factors to overtraining.
\end{abstract}

\begin{abstract}
Abstrakt
Rodiče nejsou pouze podněcovateli sportovní participace, mají významný vliv na způsob, jakým mladý sportovec vnímá a interpretuje zkušenosti ve sportovním prostředí. Motivační klima vytvárené rodiči není omezeno na sportovní prostředí, ale ovlivňuje dítě i v prostředí mimo sport. Kvalita vztahu rodič-dítě je považována za prediktor motivace, míru vnímaného stresu a potěšení ze sportovních aktivit u mladého sportovce. Přetrénování má multifaktoriální povahu, což naznačuje, že i stres z prostredí mimo sport může být faktorem, který prispívá k jeho rozvoji. Hlavním cílem této studie je poskytnout přehled výzkumných studií zkoumajících rodičovské motivační klima v kontextu vrcholového sportu a jeho potenciální vliv na mladého vrcholového sportovce. Tato studie dále poskytuje teoretický podklad k problematice rodičovského motivačního klima v kontextu sportovní participace. Byl proveden přehled studiís kvantitativním a kvalitativním výzkumným designem. Ze všech vyhledaných prací mezi lety 1992 až 201614 studií naplnilo kritéria výběru. Byly nalezeny dvě kvalitativní studie zaměrené na rodičovské motivační klima a jeho vztah k přetrénování. Tyto studie podporují předpoklad, že mimosportovní stres přispivá k rozvoji přetrénování. Doposud žádná studie s kvantitativním výzkumným designem nezkoumala prímo tento vztah. Nicméně tyto studie potvrzují vztah mezi rodičovským motivačním klima a psychologickými aspekty sportovní participace (např. maladaptivní vzorce chování), které jsou považovány za rizikové faktory pro rozvoj přetrénování.
\end{abstract}


Keywords: parent, motivational climate, overtraining, youth sport, sport participation, performance

Klíčová slova: rodič, motivační klima, přetrénování, dětský sport, sportovní participace, výkon

\section{INTRODUCTION}

Overall child development is dependent on cognitive development and social experience, which is happening through interpersonal relationships - interactions and group processes. Based on research in developmental psychology children develop mainly through shared activities and through communication with others. Thus their development is necessarily influenced by these shared activities and significant others. In sports psychology, parents, peers, teacher/coach are considered as significant others. The influence of significant others is relative considering stage of development and social context (Weigand, Carr, Petherick \& Taylor, 2001), but parents are the main socializing agent in children's life (O'Rourke et al., 2014), therefore they can influence to a great extent their child in many different ways. Parents are the gatekeepers of opportunities for the children, even for sports opportunities (Machado de Matos, 2010) and as Jayanthi, Pinkham, Fugas, Patrick and LaBella (2012) say, parents are the strongest influence on the initiation of a sport.

Nowadays sports are becoming more popular and integral part of everyday life of the majority of the population since early childhood. Generally, the society regards successful elite athletes as role models and dedicates them significant recognition and financial rewards for their achievements. Due to that many children and adolescents desire and attempt to achieve the elite level in sports and as a result recreational free play for enjoyment and fun of young children has changed into adult-driven structured, deliberate practice (Jayanthi et al., 2012). Parents are not only the gatekeepers for sports opportunity, but they also significantly influence child's view of sports experience (Machado de Matos, 2010). The young athlete is influenced by parents through the motivational climate that may be of different nature, consequently, it affects a child in different ways and may have a significant influence on child's outcomes in sports (White, 1998).

The main purpose of this study is to map theoretical background and review empirical research examining the parent-initiated motivational climate in the context of sport participation. Further, the study provides the integration of knowledge connected with the issue of parent-initiated motivational climate and its possible role in the development of overtraining syndrome, that may serve for future research.

\section{Sport as social context}

Sports are inherently complex social environments (Hellstedt, 1995) and social contexts that intersect with other social contexts important in child development (e.g., family, education, community, culture, economic systems) (Wiesse-Bjornstal, Lavoi \& Omli, 2009). Children can develop many different skills and abilities through sports activities. Coach, peers and even parents are an integral part of sports context, therefore sports are ideal environments for child development. All mentioned significant others have a notable influence on children's outcomes connected with sport participation, such as values, attitudes, perception of their own competence, motivational factors and interpersonal relationships (O'Rourke et al., 2011).

Rees and Hardy (2000) mentioned the importance of the support of significant others, because of their key role in the life of children, but as O'Rourke and his colleagues (2014) pointed out, parents are the main socializing agent in child's life. In case of child's sports experience parental role is ranging from a driver (to and from training and games) to more complex role such as being 
a coach in official or unofficial way (Côté \& Hay, 2002). Moreover, parents have the prominent impact on child's motivation, behaviour, affect, goal orientation, sense of competency and psychological growth (Bronfenbrenner \& Morris, 1998 in Holt, Tamminen, Black, Mandigo \& Fox, 2009; Brustad, Babkes \& Smith, 2001 in Force, 2011). Lack of support or its complete absence may have negative consequences.

\section{Achievement goal theory}

Nicholls (in Roberts \& Treasure, 1993) presented two conceptions of ability that manifest in achievement contexts - task involved conception of ability and ego involved conception of ability. He also contends that above mentioned conceptions of ability are embedded within two independent achievement goal orientations. Within sports contexts, these goals are termed mastery and competitiveness. Achievement contexts are conceptualized through the goal structures and expectations that shapes perspectives on success, referred to as achievement climates (Gustafsson, Hill, Stenling \& Wagnsson, 2015). Ames (1992, in Gustafsson et al., 2015) identified two motivational climates, namely a task-involving climate and ego-involving climate. The influence of significant others is usually mediated through motivational climate which they create (Keegan et al., 2009; Keegan et al., 2014).

A person with a mastery goal perspective concerns with demonstrating mastery of the task and employs a task involved conception of ability where perceptions of ability are self-referenced and dependent upon learning or improvement at the task. This goal perspective is developed usually in the environment where mastery approach is determined to be important (Roberts \& Treasure, 1993) specifically, a task-involving motivational climate where effort, cooperation and learning new skills are emphasized and rewarded (Gustaffson et al., 2015).

Conversely, a person with a competitive goal perspective is concerned with demonstrating ability compared to others. This person involves ego conception of ability and his/her perceptions of ability are based on the subjective comparison of one's ability with that of others, therefore are other referenced. This goal orientation is commonly present in environments where the social comparison is extant (Roberts \& Treasure, 1993), namely ego-involving motivational climate where is reinforced within-group competition and mistakes are punished (Gustafsson et al., 2015).

Both types of motivational climate may influence young athlete and his/her view of competences, achievement contexts and overall sport experience in different way. Focusing on the sport environment, the motivational climate may be initiated by parents, coaches and peers. All of them play an important role in the life of young athlete and may significantly influence his/her sport experience. Their influence is relative to the developmental stage of young elite athlete (Weigand et al., 2001; Keegan et al., 2014).

Tab. 1 shows summary of psychological outcomes associated with ego-involving and task-involving motivational climate based on researches, that were presented by White (1998) and Force (2011). In general, a task involving climate is associated with adaptive motivation-related responses and an ego-involving climate with maladaptive motivation-related responses. This is evident in sport where the comparative benefits of a task-involving climate have received extensive support (e.g. Roberts \& Treasure, 1993; White, 1998; Gustafsson et al., 2015). 
Tab. 1: Summary of psychological outcomes associated with motivational climate (White, 1998)

\begin{tabular}{|c|c|}
\hline $\begin{array}{l}\text { Type of motivational } \\
\text { climate }\end{array}$ & Psychological outcomes connected with sport \\
\hline $\begin{array}{l}\text { Ego-involving } \\
\text { motivational climate }\end{array}$ & $\begin{array}{l}\text { - High ability and deceptive behaviours (e.g. cheating) lead to success in sport } \\
\text { (White \& Zellner, 1996) } \\
\text { - Rewards and praise are given to individuals who reach the highest normative } \\
\text { standard or goal (Papaioannou, 1994, 1995) } \\
\text { - Performance worry and low levels of satisfaction and enjoyment (Seifriz, Duda } \\
\text { \& Chi, 1992; Walling, Duda \& Chi, 1993) } \\
\text { - Possible development of negative affective responses (Duda, } 1992 \text { in White, } \\
\text { 1998) } \\
\text { - Competitive trait anxiety (White, 1998) } \\
\text { - Self-worth based on the success in sports, contingent self-esteem, physical ex- } \\
\text { - haustion, and psychological and physical ill-being (Reinboth \& Duda, 2004) } \\
\text { - Drop out of sport (White \& Duda, 1994, in White, 1998) }\end{array}$ \\
\hline $\begin{array}{l}\text { Task-involving } \\
\text { motivational climate }\end{array}$ & $\begin{aligned} \text { - } & \text { High levels of enjoyment, even in losing situation (Seifriz et al., 1992) } \\
\text { - } & \text { Great value placed on the principles of fair play (Papaioannou, 1994, 1995) } \\
\text { - } & \text { Involvement in sport for fitness, social cooperation, and skill development } \\
& \text { (Walling et al., 1993) } \\
\text { - } & \text { Success in sport is achieved via hard work and intrinsic interest in the activity } \\
& \text { (White \& Zellner, 1996) } \\
\text { - } & \text { Positive affect in sport participants and reduced negative responses (Duda } \\
& \text { 1996) } \\
\text { - } & \text { Facilitation of positive outcomes (e.g. self-esteem, sportspersonship, persis- } \\
& \text { tence, task perseverance) (Ntoumanis \& Biddle, 1999) } \\
\text { - } & \text { Intrinsic motivation (Petherick \& Weigand, 2002, in Force, 2011) } \\
\text { - } & \text { Reducing negative responses such as overtraining and self-handicaping (Ntou- } \\
& \text { manis \& Biddle, 1999) }\end{aligned}$ \\
\hline
\end{tabular}

\section{Elite sport}

Dovalil (2004) presents elite sport as a performance at the highest level, beyond spare time, that requires adaptation of ahlete's lifestyle and daily routine. Hodaň (2007) explains elite sport as an area of gymnastic activity, which is focused on achieving relative or top performance, winning and participation in institutionally lead competitions. Sekot (2014) defines elite sports as a sport activity aimed at achieving victories and championship titles.

Bloom (1985), who one of the first studied talent development in world-class performers, divided career of talented athletes into three distinct stages:

1. the early years so-called "the Romance Phase" - exploring and development of love for the activity, fun, encouragement and emphasis on hard work;

2. the middle years labeled as "the Precision Phase" - systematic learning of skills, development of technique and technical mastery;

3. the later years called "the Integration Phase" - many hours of practices and training during the day to achieve and maintain optimal performance (in Hedstrom \& Gould, 2004).

More recently Côté (1999), based on in-depth interviews with elite athletes and their families, found out that parents play an important role in the development of athlete talent and split the career also into three stages as Bloom did, but age-specifically: 
1. the sampling years (ages 6-13) - participation in multiple sports for fun, emphasis on overall development and encouragement of participation in a wide variety of sports;

2. the specializing years (ages 13-15) - focus on a limited number of sports, little pressure, optimization of child's participation, parents take on follower or supporter versus leadership role;

3. the investment years (ages 15 and over) - deliberate practice aiming to achieve performance excellence (in Hedstrom \& Gould, 2004; Fraser-Thomas, Côté \& Deakin, 2008).

Bloom (1985) and Côté (1999) emphasized the gradual development of athlete's talent and acknowledged the importance of respecting natural and gradual overall development of a child. Nevertheless, Gould and Carson (2004) pointed out that in practice the process of athletic talent development is seldom understood, that results in inappropriate practices. Consequently, youths are increasingly specializing in sports at a younger age (Rearick, Creasy \& Buriak, 2011), even though early single sport specialization has not been shown to improve future athletic performance, conversely has been shown to be detrimental (physically and emotionally) (Capranica \& Millard-Stafford, 2011; Smucny, Parikh \& Pandya, 2015).

The more involved child becomes in sports and the better young athlete becomes, the more the pressure grows, not only on them but also on their parents (Gould, Horn \& Spreeman, 1983). Parental pressure plays a major role in the way young elite athletes perceive their sports experience. In some ways, the certain amount of pressure may be tolerated, desirable and even perceived as beneficial or an expression of support. Conversely on the other end of this continuum, there is excessive pressure that may have negative consequences on young elite athlete such as experience of stress and anxiety, de-motivation, discouragement and even withdrawal from the competitive environment (Stroebel, 2006) and it leads to an increasing number of acute and chronic injuries (Rearick, Creasy \& Buriak, 2011). Parental pressure in combination with ego-involving motivational climate coach- or parent-initiated has detrimental impact on young elite athlete as suggested Krane and colleagues (1997), Machado de Matos (2010), and O’Rourke and colleagues (2011).

Therefore, it is important for adults involved in sports experience of young elite athlete, especially for parents, to bear in mind that different children can tolerate different degrees of direction (such as involvement, support, and pressure) (Lee \& MacLean, 1997) above that child's needs and wishes should always be respected by adults (Wiersma, 2000).

\section{From normal training to overtraining}

The athlete's body must be overloaded in order to stimulate adaptive processes and to reach new levels of fitness (Carter, Potter \& Brooks, 2014), but also must avoid the combination of excessive overload plus inadequate recovery. Short-term performance decrement, without severe psychological, or lasting other negative symptoms is considered as a normal part of training programmes (Meeusen, Duclos, Foster et al., 2013). Positive adaptation or improvement in performance may follow after acute fatigue with an adequate rest period. If the balance between training stress and adequate recovery is disrupted, an abnormal response to training may occur (Machado de Matos, 2010; Meeusen, Duclos, Foster et al., 2013).

Overloading the body in training programme may result in the state of overreaching (OR) (Carter et al., 2014). This state has been defined by Sims (2001, in Carter et al., 2014) as, "an accumulation of training and nontraining stress resulting in short-term decrement in performance capacity with or without related physiological and psychological signs and symptoms of overtraining in which restoration of performance capacity may take from several days to several weeks". State of overreaching can be beneficial and even necessary for well-trained athlete in order to perform better, this is called functional overreaching (FOR). In case that necessary recovery does not occur, performance and fitness may begin to decrement and the body reach the state 
of non-functional overreaching (NFOR) and potentially develop overtraining syndrome (OTS) (Carter et al., 2014). Sims (2001, in Carter et al., 2014) has defined overtraining (OT) as, "an accumulation of training or nontraining stress resulting in long-term decrement in performance capacity with or without physiological and psychological signs and symptoms of overtraining in which restoration of performance capacity may take several weeks or months".

There is no clear distinction or assessment to determine if an individual has reached a state of NFOR and/or OTS. Usually the only difference is the time needed for the recovery (Carter et al., 2014). Therefore, OTS is a complicated issue to study because its effects are highly individualistic, people have different stress capacities, and researcher is unable to determine if individual developed OTS or NFOR until after the conclusion of the study or episode (Sims, 2001; Meeusen, Duclos, Foster et al., 2013). Another issue about studying OTS is the fact, that researchers are not uniform when defining and describing OT (Winsley \& Matos, 2010), hence Machado de Matos (2010) summarizes terms that have been used to describe or define (OT) include: staleness, burnout, unexplained underperformance syndrome, non-functional overreaching, overwork, undeperformance, underrecovery, and short- and long-term overtraining. Moreover, Fry et al. (1991) presented more than 90 different symptoms reported by overtrained athletes comprising performance, physiological and psychological factors. Based on the inconsistency in definition, description and diagnostic indicators there may be discrepancies in diagnosis and treatment of NFOR/OTS. The patient population not seeking treatment must also be considered, therefore it is common that NFOR/OTS are undiagnosed (Myrick, 2015).

In sport psychology, OT is not considered as a single entity, many researchers rather consider states of OR and OTS as a continuum of related and progressive conditions (Fry, Morton \& Keast, 1991; Winsley \& Matos, 2010), that is shown in Fig. 1 (adapted from Meeusen, Duclos, Foster et al., 2013).

\begin{tabular}{|c|c|c|c|c|}
\hline PROCESS & $\begin{array}{c}\text { TRAINING } \\
\text { (overload) }\end{array}$ & \multicolumn{3}{|c|}{ INTENSIFIED TRAINING } \\
\hline OUTCOME & $\begin{array}{c}\text { ACUTE } \\
\text { FATIGUE }\end{array}$ & $\begin{array}{c}\text { FOR } \\
\text { (short-term OR) }\end{array}$ & $\begin{array}{c}\text { NFOR (extreme } \\
\text { OR) }\end{array}$ & OTS \\
\hline RECOVER & Day(s) & Days-weeks & Weeks-months & Months - \\
\hline PERFORMANCE & INCREASE & $\begin{array}{c}\text { Temporary performance } \\
\text { decrement } \\
\text { (e.g., training camp) }\end{array}$ & $\begin{array}{c}\text { STAGNATION } \\
\text { DECREASE }\end{array}$ & DECREASE \\
\hline
\end{tabular}

Notes: FOR = functional overreaching, OR = overreaching, NFOR = non-functional overreaching, OTS = overtraining syndrome

Fig. 1: Continuum of overreaching and overtraining syndrome (Meeusen, Duclos, Foster et al., 2013)

\section{Risk factors}

Winsley and Matos (2010) contend that a common mistake about overtraining is that it is simply issue about excessive training loads. Nevertheless, Meehan, Bull, Wood, and James (2004) and Machado de Matos (2010) presented that overtraining is multifactorial in nature, high selfreported stress levels (directly or indirectly related to training) may be one of contributing factors (MacKinnon, 2000). It is in accordance with The Multisystemic model of overtraining that has been created by Meyers and Whelan (1998 in Meehan, Bull, Wood \& James, 2004; Andersen $\&$ Hanrahan, 2014). Above mentioned model is a broader perspective suggesting that the overtraining is complicated multifactorial issue. The model is shown in Fig. 2 (adapted from Meehan, Bull, Wood \& James, 2004). 


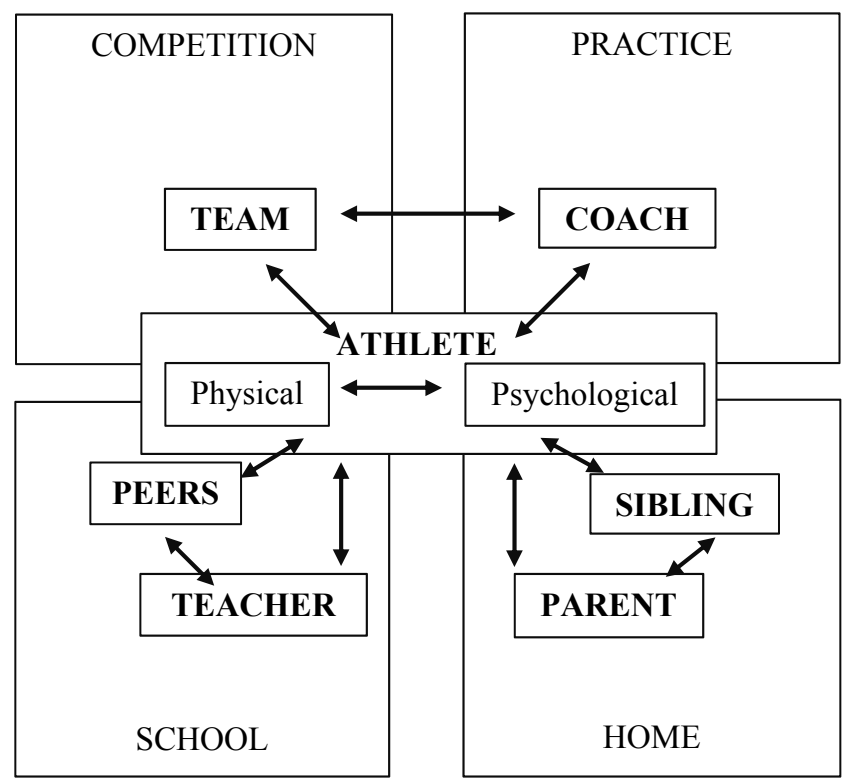

Fig. 2: The Multisystemic model of overtraining (Meehan, Bull, Wood \& James, 2004)

Recently Richardson et al. (2008 in Winsley \& Matos, 2010) provided a summary of proposed risk factors that may play an important role in developing a state of OT: training issues, situational and environmental stressors, people issues, athletes' physical condition, athletes' beliefs and attitudes. The importance of psychological and/or social stressors in addition to physiologic stress in the development of NFO/OTS has been highlighted also by researches (e.g., Kenttä \& Hassmén, 1998; Meehan, Bull, Wood et al., 2004; Tenenbaum, Jones, Kitsantas et al., 2003; Winsley \& Matos, 2010; Matos, Winsley \& Williams, 2011). Athletes are putting a lot of pressure on themselves to meet or exceed their parents' or their own expectations, which increases the risk of OT. In case of high expectations, not achieving them may cause feelings of guilt, that may be a stressor which exacerbates the situation (Matos, Winsley \& Williams, 2011). Thus, highly motivated young athletes, who are pressured by their parents and coaches to outdo predecessors, outshine contemporaries, and outperform competitors may be considered at risk for OTS (Brenner, 2007). These young athletes should be mentored and monitored to avoid overparticipation and overtraining (Faigenbaum, 2009).

It is obvious that overtraining syndrome is not only about issues associated with training programme, but athlete's social environment may play a significant role as a contributing factor in the development of overtraining syndrome. As stated above motivational climate initiated by coaches or parents plays an important role in sports environment. Through the climate they may influence young athlete's attitude and behaviour in sport. Despite the fact, that parents play an important role in the psychosocial development of their child, the influence of parent-initiated climate has not been studied by sports psychologists as much as the coach-initiated motivational climate. Based on the information from PsycINFO search facility (August 2013) 123 researches regarding the motivational climate were published, 94 studies focused on coach-initiated climate and only 29 studies focused on the parent-initiated motivational climate (O'Rourke et al., 2014). Motivational climate created by parents affects differently individual's well-being, level of perceived stress, anxiety etc. 


\section{METHOD}

The review includes studies with quantitative and qualitative approach in the period from 1992 to 2016. The beginning of the period was set because of the development of Parent-initiated motivational climate questionnaire (PIMCQ-1) by White and colleagues (1992) and the definition of the term "motivational climate", in accordance with Ames's terminology (1992, in Gustafsson et al., 2015). Therefore, this period was considered to be a period with relevant studies. Survey was done through electronic databases: EBSCO, ProQuest Central, ScienceDirect, Taylor \& Francis, ResearchGate, PsycINFO/PsycARTICLES, Elsevier. The databases were searched through using these key words: parent, motivational climate, overtraining, youth sport, sport participation, performance. Then relevant studies were chosen if they fulfilled the criteria. Lastly, all relevant studies were read, the decision which studies fulfill the criteria set was made and on this basis irrelevant studies were removed. The criteria set was follows:

1. quantitative or qualitative research design,

2. the aim of the study was to examine the relationship between parent-initiated motivational climate and psychosocial outcomes associated with sport participation, and

3. the study was grounded in achievement goal theory (Nicholls, 1984, 1989, 1992, in Roberts \& Treasure, 1993; Ames, 1992, in Roberts \& Treasure, 1993).

Although some studies differ in a research design and a theoretical framework, none was excluded because of their indirect relation to motivational climate, that was revealed after in-depth survey.

\section{RESULTS}

14 studies fulfilled the above mentioned criteria set, the overview of studies examining parent-initiated motivational climate in the context of elite sport participation is shown in Tab. 2.

Tab. 2: Preview of studies examining parent-initiated motivational climate

\begin{tabular}{|c|c|c|c|c|}
\hline STUDY & SAMPLE & MEASURE & AIMS & RESULTS \\
\hline $\begin{array}{l}\text { White et al. } \\
\text { (1992) }\end{array}$ & $\begin{array}{l}\mathrm{N}=210 \text { adolescents from } \\
\text { variety of sports }\end{array}$ & $\begin{array}{l}\text { Parent-initiated } \\
\text { motivational climate } \\
\text { questionnaire-1 (PIMCQ-1) }\end{array}$ & $\begin{array}{l}\text { To examine the factor } \\
\text { structure of the PIMCQ-1 }\end{array}$ & $\begin{array}{l}\text { 1. A three-factor structure } \\
\text { emerged: worry-conducive } \\
\text { climate, success without effort } \\
\text { climate and learning-oriented } \\
\text { climate; } \\
\text { 2. Differences between the sexes } \\
\text { emerged in the perception of } \\
\text { motivational climate }\end{array}$ \\
\hline White (1996) & $\begin{array}{l}\mathrm{N}=204 \text { female volleyball } \\
\text { players }\end{array}$ & $\begin{array}{l}\text { Parent-initiated } \\
\text { motivational climate } \\
\text { questionnaire-2 (PIMCQ-2) }\end{array}$ & $\begin{array}{l}\text { To examine the relationship } \\
\text { between goal orientation } \\
\text { and perceptions of parental } \\
\text { motivational climate }\end{array}$ & $\begin{array}{l}\text { 1. Perceptions of a success } \\
\text { without effort climate were } \\
\text { significantly correlated with } \\
\text { ego orientation; } \\
\text { 2. Perceptions of a learning/ } \\
\text { enjoyment climate were } \\
\text { significantly associated with } \\
\text { task orientation }\end{array}$ \\
\hline
\end{tabular}




\begin{tabular}{|c|c|c|c|c|}
\hline STUDY & SAMPLE & MEASURE & AIMS & RESULTS \\
\hline $\begin{array}{l}\text { Krane et al. } \\
\text { (1997) }\end{array}$ & $\begin{array}{l}N=1 \\
\text { former elite gymnast }\end{array}$ & $\begin{array}{l}\text { Three unstructured } \\
\text { interviews grounded } \\
\text { in a feminist view of sport } \\
\text { and research }\end{array}$ & $\begin{array}{l}\text { To understand and explain } \\
\text { the behaviour of gymnast, } \\
\text { her coaches, and her } \\
\text { parents based on social } \\
\text { cognitive approach to } \\
\text { achievement motivation }\end{array}$ & $\begin{array}{l}\text { 1. Three dimensions were } \\
\text { identified: motivational } \\
\text { climate (coach- and parent- } \\
\text { initiated), evidence of an ego } \\
\text { orientation and correlates of } \\
\text { ego involvement (reliance on } \\
\text { social comparison, emphasis } \\
\text { on external feedback, need to } \\
\text { demonstrate superiority, and } \\
\text { acting out behaviours in the } \\
\text { face of adversity); } \\
\text { 2. Gymnast practiced and } \\
\text { competed while seriously } \\
\text { injured, employed unhealthy } \\
\text { eating practices, overtrained, } \\
\text { and refused to listen to } \\
\text { medical advice in order to } \\
\text { continue her quest towards } \\
\text { the Olympic team }\end{array}$ \\
\hline White (1998) & $\begin{array}{l}\mathrm{N}=279 \text { (149 females } \\
\text { and } 130 \text { males) } \\
\text { adolescents from a variety } \\
\text { of sports }\end{array}$ & PIMCQ-2 & $\begin{array}{l}\text { To examine the combined } \\
\text { effects of task and ego } \\
\text { orientations on perceptions } \\
\text { of parental motivational } \\
\text { climate }\end{array}$ & $\begin{array}{l}\text { 1. Sport participants high in task } \\
\text { and low in ego orientation } \\
\text { perceived a mastery climate; } \\
\text { 2. Sport participants high in ego } \\
\text { and low in task orientation } \\
\text { perceived a performance } \\
\text { climate }\end{array}$ \\
\hline $\begin{array}{l}\text { Jowett \& Rhind } \\
\text { (2007) }\end{array}$ & $\begin{array}{l}N=237 \\
(120 \text { males and } 117 \\
\text { females) adolescent } \\
\text { athletes from variety of } \\
\text { sports }\end{array}$ & $\begin{array}{l}\text { PIMCQ-2; Elite Athlete Self- } \\
\text { Description Questionnaire } \\
\text { (EASDQ) }\end{array}$ & $\begin{array}{l}\text { To examine impact of the } \\
\text { perceived parental climate } \\
\text { on athletes' perceptions of } \\
\text { competence and ability }\end{array}$ & $\begin{array}{l}\text { 1. Parental mastery and ego } \\
\text { climate predicted physical } \\
\text { self-concept of young athlete; } \\
\text { 2. Fathers are the strongest } \\
\text { influence in shaping athletes' } \\
\text { physical self-concept } \\
\text { (positively and negatively); } \\
\text { 3. Young adolescent athletes' } \\
\text { physical self-concept is } \\
\text { more strongly affected by } \\
\text { motivational climate than } \\
\text { old adolescent athletes'self- } \\
\text { concept }\end{array}$ \\
\hline $\begin{array}{l}\text { Machado } \\
\text { de Matos (2010) }\end{array}$ & $\begin{array}{l}\mathrm{N}=1 \text { national-level } \\
\text { swimmer }\end{array}$ & $\begin{array}{l}\text { Athlete Burnout } \\
\text { Questionnaire }(A B Q) \text {; semi- } \\
\text { structured interview }\end{array}$ & $\begin{array}{l}\text { To explore the experiences } \\
\text { and views of a young } \\
\text { female swimmer who } \\
\text { was in an active BO state } \\
\text { by using Interpretive } \\
\text { Phenomenological Analyses }\end{array}$ & $\begin{array}{l}\text { 1. Athlete Burnout Questionnaire } \\
\text { confirmed her as an active } \\
\text { burnout (high scores in } \\
\text { reduced accomplishment and } \\
\text { sport devaluation constructs; } \\
\text { 2. The case study has shown that } \\
\text { overtraining and burnout are } \\
\text { multifactorial in nature; } \\
\text { 3. The case study supports the } \\
\text { possibility that overtraining } \\
\text { and burnout are part of } \\
\text { a continuum with B0 as the } \\
\text { final result and that eventually } \\
\text { leads the athlete to withdraw } \\
\text { from sport. }\end{array}$ \\
\hline
\end{tabular}




\begin{tabular}{|c|c|c|c|c|}
\hline STUDY & SAMPLE & MEASURE & AIMS & RESULTS \\
\hline $\begin{array}{l}\text { O'Rourke et al. } \\
\text { (2011) }\end{array}$ & $\begin{array}{l}N=307 \\
(122 \text { males, } 185 \text { females }) \\
9-14 \text { y.o. swimmers }\end{array}$ & $\begin{array}{l}\text { PIMCQ-2; Directive Behavior } \\
\text { Scale; Sport Anxiety Scale-2 } \\
\text { (SAS-2) }\end{array}$ & $\begin{array}{l}\text { To assess the role of } \\
\text { parental behaviors on sport } \\
\text { performance anxiety }\end{array}$ & $\begin{array}{l}\text { 1. High parental pressure } \\
\text { within either a low mastery } \\
\text { or a high ego climate was } \\
\text { associated with the highest } \\
\text { levels of anxiety; } \\
\text { 2. An early-season high } \\
\text { pressure/low mastery } \\
\text { combination was associated } \\
\text { with relative increases in } \\
\text { anxiety over the season; } \\
\text { 3. High pressure within } \\
\text { high mastery climate was } \\
\text { associated with relative } \\
\text { decreases in anxiety over } \\
\text { the season }\end{array}$ \\
\hline Force (2011) & $\begin{array}{l}\mathrm{N}=405 \\
8 \text { th grade male athletes } \\
\text { from variety of sports }\end{array}$ & $\begin{array}{l}\text { PIMCQ-2; Task and Ego } \\
\text { Orientation in Sport } \\
\text { Questionnaire (TEOSQ); } \\
\text { Achievement Goal Scale } \\
\text { for Youth Sports; Sport } \\
\text { Competence subscale } \\
\text { and Global esteem } \\
\text { (Physical Self-Description } \\
\text { Questionnaire, PSDQ); } \\
\text { Enjoyment subscale (Sport } \\
\text { Commitment Model, SCM); } \\
2 \text { questions about intention } \\
\text { to continue }\end{array}$ & $\begin{array}{l}\text { To examine relations } \\
\text { between the perceived } \\
\text { motivational climate and } \\
\text { psychological outcomes } \\
\text { experienced in sport } \\
\text { (goal orientation, sport } \\
\text { competence, self-esteem, } \\
\text { enjoyment, and intention } \\
\text { to continue participating } \\
\text { in sport) }\end{array}$ & $\begin{array}{l}\text { 1. Mastery climate was } \\
\text { associated with mastery } \\
\text { goal orientation; } \\
\text { 2. Mastery goal orientation } \\
\text { was associated with } \\
\text { greater sport competence, } \\
\text { self-esteem, and more } \\
\text { enjoyment in sport; } \\
\text { 3. Intention to continue was } \\
\text { predicted primarily by } \\
\text { level of enjoyment, and } \\
\text { secondarily by increased } \\
\text { feelings of self-esteem }\end{array}$ \\
\hline $\begin{array}{l}\text { Kavussanu et al. } \\
\text { (2011) }\end{array}$ & $\begin{array}{l}N=118 \\
69 \text { elite football players and } \\
49 \text { non-elite football players }\end{array}$ & $\begin{array}{l}\text { The Task and Ego } \\
\text { Orientation in Sport } \\
\text { Questionnaire (TEOSQ); } \\
\text { PIMCQ-2 }\end{array}$ & $\begin{array}{l}\text { To examine whether elite } \\
\text { and non-elite adolescent } \\
\text { players differ in goal } \\
\text { orientation and perceptions } \\
\text { of the motivational climate } \\
\text { created by their parents }\end{array}$ & $\begin{array}{l}\text { 1. Elite players were } \\
\text { significantly higher in } \\
\text { task orientation, and } \\
\text { had higher perceptions } \\
\text { that their mother valued } \\
\text { a motivational climate } \\
\text { that emphasized learning } \\
\text { and enjoyment, and } \\
\text { lower perceptions that } \\
\text { both parents created } \\
\text { climate in which success } \\
\text { without effort was valued, } \\
\text { compared to non-elite } \\
\text { athletes; } \\
\text { 2. The findings suggest } \\
\text { that task orientation } \\
\text { and a perceived parental } \\
\text { environment that values } \\
\text { effort and learning may } \\
\text { facilitate high levels of } \\
\text { sport achievement. }\end{array}$ \\
\hline
\end{tabular}




\begin{tabular}{|c|c|c|c|c|}
\hline STUDY & SAMPLE & MEASURE & AIMS & RESULTS \\
\hline $\begin{array}{l}0^{\prime} \text { Rourke et al. } \\
\text { (2012) }\end{array}$ & $\begin{array}{l}N=304 \\
\text { (123 males, } 181 \text { females) } \\
\text { athletes from three elite } \\
\text { swim clubs }\end{array}$ & $\begin{array}{l}\text { PIMCQ-2; Washington Self- } \\
\text { Description Questionnaire } \\
\text { (WSDQ); Self-Regulation } \\
\text { Scale }\end{array}$ & $\begin{array}{l}\text { To test propositions } \\
\text { derived from Achievement } \\
\text { Goal Theory and Self- } \\
\text { Determination Theory }\end{array}$ & $\begin{array}{l}\text { 1. At all three measurement } \\
\text { points, mastery climate scores } \\
\text { were positively related to } \\
\text { global self-esteem scores } \\
\text { and to a measure of relative } \\
\text { motivational autonomy, } \\
\text { whereas ego climate were } \\
\text { negatively related to self- } \\
\text { esteem and autonomy; } \\
\text { 2. Early-season mastery climate } \\
\text { predicted positive changes in } \\
\text { self-esteem over the course } \\
\text { season, whereas ego climate } \\
\text { predicted decreased self- } \\
\text { esteem; } \\
\text { 3. Self-esteem changes were } \\
\text { mediated by changes in } \\
\text { autonomous motivation }\end{array}$ \\
\hline $\begin{array}{l}\text { O'Rourke et al. } \\
\text { (2013) }\end{array}$ & $\begin{array}{l}N=308 \\
\text { (124 males, } 184 \text { females) } \\
\text { 9-14 y.0. swim club } \\
\text { athletes }\end{array}$ & $\begin{array}{l}\text { PIMCQ-2; Self-Regulation } \\
\text { Questionnaire }\end{array}$ & $\begin{array}{l}\text { To examine relations } \\
\text { between the motivational } \\
\text { climate created by parents } \\
\text { and both the nature and } \\
\text { changes in sport-related } \\
\text { motivation in young } \\
\text { athletes }\end{array}$ & $\begin{array}{l}\text { 1. Mastery climate was } \\
\text { associated with higher levels } \\
\text { of autonomous regulation } \\
\text { (intrinsic motivation) } \\
\text { compared to ego climate; } \\
\text { 2. Ego climate scores were } \\
\text { positively related to extrinsic } \\
\text { motivation scores }\end{array}$ \\
\hline $\begin{array}{l}\text { O'Rourke et al. } \\
\text { (2014) }\end{array}$ & $\begin{array}{l}N=238 \\
\text { ( } 97 \text { males, } 141 \text { females), } \\
\text { 9-14 y.o. competitive } \\
\text { swimmers }\end{array}$ & $\begin{array}{l}\text { PIMCQ-2; Motivational } \\
\text { Climate Scale for Youth } \\
\text { Sports (MCSYS); Sport } \\
\text { Anxiety Scale-2 (SAS- } \\
\text { 2); Self-Regulation } \\
\text { Questionnaire; Washington } \\
\text { Self-Description } \\
\text { Questionnaire (WSDQ) }\end{array}$ & $\begin{array}{l}\text { To compare strength of } \\
\text { relations between athletes' } \\
\text { late-season perception } \\
\text { of coach and parent- } \\
\text { initiated climates and their } \\
\text { self-esteem, performance } \\
\text { anxiety, and intrinsic- } \\
\text { extrinsic motivation }\end{array}$ & $\begin{array}{l}\text { 1. Parent-initiated motivational } \\
\text { climate was a significant } \\
\text { predictor of late-season } \\
\text { self-esteem, trait anxiety, and } \\
\text { autonomous regulation over } \\
\text { coach-initiated motivational } \\
\text { climate }\end{array}$ \\
\hline $\begin{array}{l}\text { Gustafsson et al. } \\
\text { (2015) }\end{array}$ & $\begin{array}{l}\mathrm{N}=237 \\
\text { (123 males, } 113 \text { females) } \\
\text { junior athletes from variety } \\
\text { of sports }\end{array}$ & $\begin{array}{l}\text { PIMCQ-2; The Athlete } \\
\text { Burnout Questionnaire } \\
\text { (ABQ); Multidimensional } \\
\text { Perfectionism Scale }\end{array}$ & $\begin{array}{l}\text { To examine whether } \\
\text { discernible groups can be } \\
\text { identified based on scores } \\
\text { of perfectionism and } \\
\text { perceptions of parent- } \\
\text { initiated climate and, then, } \\
\text { whether these groups differ } \\
\text { in terms of burnout }\end{array}$ & $\begin{array}{l}\text { 1. Latent profile analysis } \\
\text { identified four groups: } \\
\text { non-perfectionistic athletes } \\
\text { in a task-oriented climate, } \\
\text { moderately perfectionistic } \\
\text { athletes in a task-oriented } \\
\text { climate, highly perfectionistic } \\
\text { athletes in a task-oriented } \\
\text { climate, and highly } \\
\text { perfectionistic athletes in } \\
\text { a mixed climate; } \\
\text { 2. Highly perfectionistic athletes } \\
\text { in a task-oriented climate } \\
\text { and a mixed climate reported } \\
\text { higher levels of burnout in } \\
\text { comparison to other groups }\end{array}$ \\
\hline
\end{tabular}




\begin{tabular}{|c|c|c|c|c|}
\hline STUDY & SAMPLE & MEASURE & AIMS & RESULTS \\
\hline Schwebel (2015) & $\begin{array}{l}\mathrm{N}=612 \\
\text { (369 males, } 243 \text { females) } \\
\text { youth basketball players } \\
\text { from } 5 \text { recreational } \\
\text { community center } \\
\text { basketball leagues }\end{array}$ & $\begin{array}{l}\text { Parent-Attributed Standards } \\
\text { for Success; Motivational } \\
\text { Climate Scale for Youth } \\
\text { Sports (MCSYS); The } \\
\text { Achievement Goal Scale for } \\
\text { Youth Sports (AGSYS); The } \\
\text { Sport Anxiety Scale-2 } \\
\text { (SAS-2); The Washington } \\
\text { Self-Description } \\
\text { Questionnaire (WSDQ) }\end{array}$ & $\begin{array}{l}\text { To examine the impact of } \\
\text { the motivational climates } \\
\text { created by parents and } \\
\text { coaches on post-season } \\
\text { athlete outcomes of } \\
\text { anxiety, self-esteem } \\
\text { and achievement goal } \\
\text { orientation }\end{array}$ & $\begin{array}{l}\text { 1. Perceived parent success } \\
\text { standards were a significant } \\
\text { predictor of youth outcomes } \\
\text { over and above coach } \\
\text { motivational climate }\end{array}$ \\
\hline
\end{tabular}

The issue of parent-initiated motivational climate has been studied by qualitative research design using unstructured (Krane et al., 1997) or semi-structured (Machado de Matos, 2010) interviews. The first mentioned case study revealed the relationship between ego-involving motivational climate (initiated by parents and coach), ego-involved goal orientation and maladaptive behavioural patterns (e.g., competing while seriously injured, unhealthy eating practices, not listening to medical advice and even presence of overtraining) (Krane et al., 1997). Machado de Matos (2010) presented another case study, that is about young talented successful swimmer who only focused on one sport, had "pushy mum" and father who took sport very competitively. The parents' mentality of being "in it to win it" became a very strong feature in her personality, consequently she developed a performance based self-esteem. Thus athletes easily become stressed because they are continuously at the mercy of a good performance. She was constantly moody and angry, had communication issues with coaches, her performance deteriorated, however she still maintained the motivation to continue in the sport. That is in accordance with ego goal orientation and also ego-involved motivational climate initiated by parents. The swimmer experienced overtraining several times in the past and was even diagnosed as overtrained.

Research studies examining parent-initiated motivational climate with quantitative approach are longitudinal (e.g., O'Rourke et al., 2011; O'Rourke et al., 2012; O'Rourtke et al., 2013), crosssectional (e.g., White et al., 1992; Force, 2011; Kavusanu et al., 2011; Gustafsson et al., 2015; Jowett \& Rhind, 2007) in nature, albeit the latter data were more common. Researchers usually focused on the relation between parent-initiated motivational climate and motivation, trait or performance anxiety, self-esteem, goal orientation of young athlete.

The findings presented in Table 2 revealed that parent-initiated motivational climate involving ego is more commonly associated with higher trait and performance anxiety levels, lower self-esteem, extrinsic motivation, ego-involved goal orientation, less sports enjoyment, negative self-concept. Whereas, parent-initiated motivational climate involving task orientation revealed opposite results. White and colleagues (1992) found out significant differences between how boys and girls perceived their parents' reactions to their learning new skills. In contrast to boys, girls thought that both their mothers and fathers focused on improvement and self-satisfaction during the learning process and deemphasized learning without effort and worrying about making mistakes. Age did not significantly affect the perceptions individuals had of the parent-initiated motivational climate (White et al., 1992). However, Weigand and colleagues (2001) pointed out a developmental shift in the influence of specific significant others on goal orientations. They found out that parental and coach influence might be more profound in childhood, and peer influence might predominate in adolescence. O'Rourke with colleagues (2014) and Schwebel (2015) examined the relative impact of parent- and coach-initiated climate. Both studies supported greater influence of parent-initiated motivational climate compared to the motivational climate initiated by coach. Parents interact with children in a variety of ways related to sport experience, and also related to non-sport experience, achievement and competence domain, such as school and social 
settings. As a result of intense and long-term parent-child relationship, parents can significantly shape their child's level of internalization of ideals, motivations, and attitudes as they relate to sport (O'Rourke et al., 2014).

\section{DISCUSSION}

Presented findings (see Tab. 1, and Tab.2) compared to task motivational climate, ego motivational climate has more negative impacts on athlete. However, Abrahamsen and Kristiansen (2015) pointed out that task climate may also create stress and anxiety. Findings of their study revealed that stress may occur when there is a discrepancy between set values and actual value. Thus, when athletes are more accustomed to being evaluated normatively for the team roster, a sudden emphasis on personal improvement and maximum effort is very different - and may simply stress athletes even in task-involved environment. Gustafsson and his colleagues (2015) found out that highly perfectionistic athletes in a task-oriented climate and a mixed climate presented higher levels of burnout (BO) compared to other groups. This finding suggest that higher perfectionism among junior athletes might be a risk factor for higher BO no matter the type of motivational climate. Further, authors explain this greater risk because young athletes perceive their parents emphasizing concerns about failure and winning without trying one's best. Despite this finding in sport psychology task involving climate is typically recommended to avoid unnecessary stress and performance anxiety (O'Rourke et al., 2011; O'Rourke et al., 2014; Gustafsson et al., 2015; Schwebel, 2015) and motivational climate involving ego have been shown to be related to maladaptive aspects of motivation unless ability is perceived high (Weigand et al., 2001).

In past, training stress has been reported to be the principal factor that contributes to the development of OTS. Nevertheless, more recently it has been suggested that also non-sport stress may play an important role in the development of OTS. Consequently, the multisystemic model of overtraining has been developed, in which athletes are viewed as the major mediator between the stimuli in the environment and the resulting responses (Meehan et al., 2004). Moreover, in case studies presented by Meehan and colleagues (2004), all five participants diagnosed as OT identified nonsport stress as a contributing factor of their symptoms. Krane and colleagues (1997), and Machado de Matos (2010) revealed the relationship between initiated motivational climate and overtraining/burnout. Based on the case study of Machado de Matos (2010), in which swimmer had strong parent-initiated motivational climate involving ego and had past experiences in OT, we assume that parental motivational climate may contribute in developing the overtraining syndrome, albeit the nature of relationship between motivational climate and OT may not be simple as suggested Gustafsson and his colleagues (2015) in the relationship between motivational climate, perfectionism and burnout.

To our knowledge, the relationship between parent-initiated motivational climate (motivational climate in general) and OT has never been studied directly by quantitative research design. However, it is important to note that relationship between motivational climate and psychosocial outcomes such as self-esteem, adaptive or maladaptive behavioural patterns, levels of well-being, trait and performance anxiety has been revealed. According to qualitative studies presented in Tab. 2, these outcomes can potentially contribute to the development of OT. 


\section{CONCLUSION}

We see as an important to focus on the issue of parent-initiated motivational climate and its relation to overtraining, because it has not been studied widely and parents are potentially the most influential significant others in the life of child. Moreover 36\% of the parents had unknowingly emotionally hurt and interfered with their child's development (Gould, Lauer, Rolo et al., 2006). Based on the literature review and studies with quantitative and qualitative approach may suggest and apply ways of training optimization, preventive programmes and education about risk factors associated with sports and non-sports environment contributing to overtraining syndrome.

Rather than emphasizing normative and outcome-based goals, it is more important to focus on personal improvement and long-term, healthy training techniques. Because of the great impact of parents and coaches on sports and psychosocial outcomes of sports in youth elite athletes, it is important to educate them about alternate training methods and employing variety techniques that develop task-oriented motivational climate. Even though the most important thing in elite sport is to win, parents and coaches should point out the importance of enjoyment, self-satisfaction and improvement.

\section{References}

Andersen, M. B., \& Hanrahan, S. J. (Eds.). (2014). Doing exercise psychology. Human Kinetics.

Bloom, B.S. (Ed.) (1985). Developing talent in young people. NY: Ballantine.

Brenner, J. S. (2007). Overuse injuries, overtraining, and burnout in child and adolescent athletes. Pediatrics, 119(6), $1242-1245$.

Capranica, L., \& Millard-Stafford, M. L. (2011). Youth sport specialization: how to manage competition and training. International journal of sports physiology and performance, 6(4), 572-579.

Carter, J. G., Potter, A. W., \& Brooks, K. A. (2014). Overtraining syndrome: causes, consequences, and methods for prevention. Journal of Sport and Human Performance, 2(1).

Côté, J. (1999). The influence of the family in the development of talent in sport. The Sport Psychologist, 13, 395-417.

Côté, J., \& Hay, J. (2002). Family influences on youth sport performance and participation. In J. M. Silva and D. Stevens (Eds.), Psychological foundations of sport (pp. 503-519). Boston, MA: Allyn \& Bacon.

Dovalil, J. (2004). Olympismus. Praha: Olympia.

Duda, J. L. (1996). Maximizing motivation in sport and physical education among children and adolescents: The case for greater task involvement. Quest, 48(3), 290-302.

Faigenbaum, A. D. (2009). Overtraining in young athletes: How much is too much? ACSM's Health \& Fitness Journal, 13(4), 8-13.

Force, E. C. (2011). The parent-initiated task motivational climate and factors influencing eighth grade boys' intention to continue sports (Disertation). North Texas.

Fraser-Thomas, J., Côté, J., \& Deakin, J. (2008). Examining adolescent sport dropout and prolonged engagement from a developmental perspective. Journal of applied sport psychology, 20(3), 318-333.

Fry, R. W., Morton, A. R., \& Keast, D. (1991). Overtraining in athletes. Sports Medicine, 12(1), 32-65.

Gould, D., Horn, T. \& Spreeman, J. (1983). Sources of stress in junior elite wrestlers. Journal of Sport Psychology, 5: 159-171.

Gould, D., Lauer, L., Rolo, C., Jannes, C., \& Pennisi, N. (2006). Understanding the role parents play in tennis success: a national survey of junior tennis coaches. British journal of sports medicine, 40(7), 632-636.

Gustafsson, H., Hill, A. P., Stenling, A., \&Wagnsson, S. (2015). Profiles of perfectionism, parental climate, and burnout among competitive junior athletes. Scandinavian Journal of Medicine \& Science in Sports.

Hedstrom, R., \& Gould, D. (2004). Research in youth sports: Critical issues status. Michigan: Michigan State University, 1-42.

Hellstedt, J. C. (1995). Invisible players: A family systems model. In S. M. Murphy (Ed.), Sport psychology interventions (pp. 117-146). Champaign, IL: Human Kinetics.

Hodaň, B. (2007). Sociokulturní kinantropologie II. Olomouc: UP.

Holt, N. L., Tamminen, K. A., Black, D. E., Mandigo, J. L., \& Fox, K. R. (2009). Youth sport parenting styles and practices. Journal of sport and exercise psychology, 31(1), 37-59.

Jayanthi, N., Pinkham, C., Dugas, L., Patrick, B., \& LaBella, C. (2012). Sports specialization in young athletes evidence-based recommendations. Sports health: a multidisciplinary approach, 1941738112464626.

Kavussanu, M., White, S. A., Jowett, S., \& England, S. (2011). Elite and non-elite male footballers differ in goal orientation and perceptions of parental climate. International Journal of Sport and Exercise Psychology, 9(3), 284-290.

Keegan, R. J., Harwood, C. G., Spray, C. M., \& Lavallee, D. E. (2009). A qualitative investigation exploring the motivational climate in early career sports participants: Coach, parent and peer influences on sport motivation. Psychology of sport and exercise, 10(3), 361-372. 
Keegan, R. J., Harwood, C. G., Spray, C. M., \& Lavallee, D. (2014). A qualitative investigation of the motivational climate in elite sport. Psychology of Sport and Exercise, 15(1), 97-107.

Kenttä, G., \& Hassmén, P. (1998). Overtraining and recovery. Sports medicine, 26(1), 1-16.

Krane, V., Snow, J., \& Greenleaf, C. A. (1997). Reaching for gold and the price of glory: A motivational case study of an elite gymnast. The sport psychologist, 11(1), 53-71.

Lee, M.J. \& MacLean, S. (1997). Sources of parental pressure among age group swimmers. European Journal of Physical Education, 2: 167-177.

Machado de Matos, N. F. (2010). Overtraining and burnout in young English athletes (Doctoral dissertation, University of Exeter).

MacKinnon, L. T. (2000). Overtraining effects on immunity and performance in athletes. Immunology and cell biology, 78(5), 502-509.

Matos, N. F., Winsley, R. J., \& Williams, C. A. (2011). Prevalence of non-functional overreaching/overtraining in young English athletes. Med Sci Sports Exerc, 43(7), 1287-94.

Meehan, H. L., Bull, S. J., Wood, D. M., \& James, D. V. (2004). The overtraining syndrome: A multicontextual assessment. The Sport Psychologist, 18(2), 154-171.

Meeusen, R., Duclos, M., Foster, C., Fry, A., Gleeson, M., Nieman, D., ... \& Urhausen, A. (2013). Prevention, diagnosis and treatment of the overtraining syndrome: Joint consensus statement of the European College of Sport Science (ECSS) and the American College of Sports Medicine (ACSM). European Journal of Sport Science, 13(1), 1-24.

Myrick, K. M. (2015). Overtraining and overreaching syndrome in athletes. The Journal for Nurse Practitioners, 11(10), $1018-1022$.

Ntoumanis, N., \& Biddle, S. J. (1999). A review of motivational climate in physical activity. Journal of sports sciences, 17(8), 643-665.

O'Rourke, D. J., Smith, R. E., Smoll, F. L., \& Cumming, S. P. (2011). Trait anxiety in young athletes as a function of parental pressure and motivational climate: is parental pressure always harmful? Journal of Applied Sport Psychology, 23(4), 398-412.

O'Rourke, D. J., Smith, R. E., Smoll, F. L., \& Cumming, S. P. (2012). Parent-initiated motivational climate, self-esteem, and autonomous motivation in young athletes: Testing propositions from achievement goal and self-determination theories. Child Development Research, 2012.

O'Rourke, D. J., Smith, R. E., Smoll, F. L., \& Cumming, S. P. (2013). Parent-initiated motivational limate and young athletes intrinsic-extrinsic motivation: cross-sectional and longitudinal relations. Journal of Child and Adolescent Behavior, 1-8.

O'Rourke, D. J., Smith, R. E., Smoll, F. L., \& Cumming, S. P. (2014). Relations of parent-and coach-initiated motivational climates to young athletes' self-esteem, performance anxiety, and autonomous motivation: who is more influential? Journal of Applied Sport Psychology, 26(4), 395-408.

Papaioannou, A. (1994). Development of a questionnaire to measure achievement orientations in physical education. Research quarterly for exercise and sport, 65(1), 11-20.

Papaioannou, A. (1995). Differential perceptual and motivational patterns when different goals are adopted. Journal of Sport and Exercise Psychology, 17(1), 18-34.

Reinboth, M., \& Duda, J. L. (2004). The motivational climate, perceived ability, and athletes' psychological and physical well-being. The Sport Psychologist, 18(3), 237-251.

Roberts, G. C., \& Treasure, D. C. (1993). The importance of the study of children in sport: An overview. Coaching children in sport: Principles and practice, 1-16.

Sekot, A. (2014). Sociologie sportu: aktuální problémy. Brno: Masarykova univerzita.

Seifriz, J. J., Duda, J. L., \& Chi, L. (1992). The relationship of perceived motivational climate to intrinsic motivation and beliefs about success in basketball. Journal of sport and exercise psychology, 14(4), 375-391.

Schwebel, F. J. (2015). Comparing the relative impact of parent-and coach-initiated motivational climates on young athletes' self-esteem, performance anxiety, and achievement goal orientation (Doctoral dissertation, University of Washington).

Sims, S. (2001). The Overtraining Syndrome and Endurance Athletes. Strength \& Conditioning Journal, 23(1), 45.

Smucny, M., Parikh, S. N., \& Pandya, N. K. (2015). Consequences of single sport specialization in the pediatric and adolescent athlete. Orthopedic Clinics of North America, 46(2), 249-258.

Stroebel, L. C. E. (2006). Parental involvement in sport: Perceptions of competitive adolescent swimmers (Doctoral dissertation, University of the Free State).

Tenenbaum, G., Jones, C. M., Kitsantas, A., Sacks, D. N., \& Berwick, J. P. (2003). Failure adaptation: psychological conceptualization of the stress response process in sport. International Journal of Sport Psychology, 34(1), 1-26.

Walling, M. D., Duda, J. L., \& Chi, L. (1993). The perceived motivational climate in sport questionnaire: Construct and predictive validity. Journal of Sport and Exercise Psychology, 15(2), 172-183.

Weigand, D., Carr, S., Petherick, C., \& Taylor, A. (2001). Motivational climate in sport and physical education: The role of significant others. European Journal of Sport Science, 1(4), 1-13.

White, S. A. (1998). Adolescent goal profiles, perceptions of the parent-initiated motivational climate, and competitive trait anxiety. The Sport Psychologist, 12(1), 16-28.

White, S. A., Duda, J. L., \& Hart, S. (1992). An exploratory examination of the parent-initiated motivational climate questionnaire. Perceptual and Motor Skills, 75(3), 875-880.

White, S. A., \& Zellner, S. R. (1996). The relationship between goal orientation, beliefs about the causes of sport success, and trait anxiety among high school, intercollegiate, and recreational sport participants. The Sport Psychologist, 10(1), 58-72. 
Wiersma, L. D. (2000). Risks and benefits of youth sport specialization: Perspectives and recommendations. Pediatric Exercise Science, 12(1), 13-22.

Winsley, R., \& Matos, N. (2010). Overtraining and elite young athletes. In: Armstrong N., McManus A.M. (eds): The elite young athlete. Med Sport Sci. Basel (Vol. 56, pp. 97-105). Karger Publishers.

Wiese-Bjornstal, D. M., Lavoi, N. M. \& Omli, J. (2009). Child and adolescent development and sport participation, in Sport Psychology (ed. B. W. Brewer), Wiley-Blackwell, Oxford, UK. doi: 10.1002/9781444303650.ch10

\section{Corresponding author:}

frydrychova.zuzka@gmail.com 